Chacón-Monge, J. L., Angulo, A., \& Cortés, J. (2021). New hosts and morphological data for the Star pearlfish Carapus mourlani (Ophidiiformes: Carapidae) from collections made in the North Pacific coast of Costa Rica. Revista de Biología Tropical, 69(Suppl. 2), S219-S233. https://doi. org/10.15517/rbt.v69iS2.48319

https://doi.org/10.15517/rbt.v69iS2.48319

\title{
New hosts and morphological data for the Star pearlfish Carapus mourlani (Ophidiiformes: Carapidae) from collections made in the North Pacific coast of Costa Rica
}

\author{
José Leonardo Chacón-Monge ${ }^{1,2}$; (D) https://orcid.org/0000-0002-9754-1254 \\ Arturo Angulo1,2; (iD https://orcid.org/0000-0002-4587-1446 \\ Jorge Cortés ${ }^{1,2}$; (D) https://orcid.org/0000-0001-7004-8649
}

1. Centro de Investigación en Ciencias del Mar y Limnología (CIMAR), Universidad de Costa Rica, 11501-2060, San José, Costa Rica; jose.chaconmonge@ucr.ac.cr, arturo.angs@gmail.com, jorge.cortes@ucr.ac.cr

2. Museo de Zoología, Centro de Investigación en Biodiversidad y Ecología Tropical (CIBET), Universidad de Costa Rica, 11501-2060, San José, Costa Rica.

Recibido 30-I-2021. Revisado 19-III-2021. Aceptado 30-V-2021.

\begin{abstract}
Introduction: The family Carapidae includes about 40 species of marine fishes distributed in coastal habitats worldwide. The family includes some free-living species, however, most of them are found as commensal inquilines or parasites of marine invertebrates, including several echinoderm species. In the Eastern Tropical Pacific, the biology and host use of the representatives of the Carapidae is relatively poorly known.

Objective: The present study reports the occurrence of the Star pearlfish Carapus mourlani within three previously unknown hosts in the region: the sea stars Nidorellia armata, Phataria unifascialis, and the sea cucumber Stichopus horrens. Some ecological implications and considerations regarding such symbiotic relationships are raised and discussed. Additional morphometric and meristic data for the fish and the echinoderms are also provided and discussed.

Methods: Echinoderms were collected, from 25 localities along the North Pacific coast of Costa Rica, and were carefully examined searching for commensal/parasitic fishes. Echinoderms and fishes were identified and characterized in accordance with the specialized literature.

Results: A total of 497 echinoderms, including about 60 species, were collected and examined. Commensal/ parasitic fish (a single species represented by 13 specimens) were found in three echinoderm specimens/species. Conclusions: The list of echinoderm hosts for this carapid fish, through its whole distribution range, rises to 12 species (six sea stars and six sea cucumbers) and that could be a consequence of its wide geographic distribution, its generalist feeding habits and opportunistic commensal behavior.
\end{abstract}

Key words: Eastern Tropical Pacific; Central America; Área de Conservación Guanacaste; symbioses; Nidorellia armata; Phataria unifascialis; Stichopus horrens.

The family Carapidae (Ophidiiformes; Pearlfishes or Asshfishes) includes eight genera and 36 species (Fricke, Eschmeyer, \& Van der Laan, 2021) of marine fishes widely distributed in coastal habitats worldwide (Machida, 1989; Meyer-Rochow, 1979; Nelson, Grande,
\& Wilson, 2016). Members of the family are diagnosed by the following combination of characters: body elongated, tapering to a slender and pointed tail; supramaxilla absent; origin of the anal fin on the anterior portion of the body, usually under vertebra 1-13 and 
closer to the pectoral fin origin (when present); pelvic fins absent (in neotropical genera); dorsal and anal fins without spines, confluent around the caudal fin; and anal fin rays longer than opposite dorsal fin rays (Nelson et al., 2016; Robertson \& Allen, 2015). Even though there are some free-living species, most carapid fishes are found as commensal inquilines (i.e., with no metabolic dependency) or parasites of bivalve mollusks, sea slugs, sea hares, sea stars, sea cucumbers, and ascidians (Glynn, Enochs, McCosker, \& Graefe, 2008; Parmentier, Lanterbecq, \& Eeckhaut, 2016; Parmentier, Mercier, \& Hamel, 2006). These remarkable associations, as well as a unique early life history (i.e, planktonic vexillifer larvae, whit a latter tenuis stage that usually requires a host for metamorphosis), account for the notoriety of the group (Markle \& Olney, 1990; Parmentier \& Vandewalle, 2005; Trott, 1981).

While the biology of several carapid fishes has received some degree of attention in recent years, especially in the Indo-West Pacific and Atlantic Oceans, the (taxonomic and morphological) diversity and ecology (including information about feeding, habitat use or preferences, behavior, and distribution, among others) of the East Pacific species remain relatively poorly known (Castro-Aguirre, García-Domínguez, \& Balart, 1996; Glynn et al., 2008; Paredes-Ríos \& Balart, 1999; Parmentier, Mercier, \& Hamel, 2006). Currently, four species (in three genera) of carapids are known to occur in the Eastern Tropical Pacific region (ETP) (Robertson \& Allen, 2015); these are: the Nocturnal pearlfish Echiodon exsilium Rosenblatt, 1961; the Worm pearlfish Encheliophis vermicularis Müller, 1842; the Pacific pearlfish Carapus dubius (Putnam, 1874); and the Star pearlfish Carapus mourlani (Petit, 1934). Regarding their ecology, E. exsilium is a free-living species; whereas E. vermicularis inhabits the guts of sea cucumbers, including Isostichopus fuscus (Ludwig, 1875) and Holothuria impatiens (Forskål, 1775); C. dubius has been found inhabiting the body cavity of pearl shells (Pinctada spp. Röding, 1798), pen shells (Pinna spp. Linnaeus, 1758), spiny oyster shells
(Spondylus crassisquama Lamarck, 1819), clams (Megapitaria spp. Grant \& Gale, 1931), cockles (Laevicardium spp. Swainson, 1840) and the sea cucumbers Apostichopus californicus (Stimpson, 1857), Holothuria sp., I. fuscus and Neothyone gibbosa Deichmann, 1941; finally, C. mourlani has been found inside I. fuscus and in the gill chamber of the sea hare Dolabella auricularia (Lightfoot, 1786) (Castro-Aguirre et al., 1996; Glynn et al., 2008; González \& Borrero-Pérez, 2020; Paredes-Ríos \& Balart, 1999; Parmentier, Mercier, \& Hamel, 2006; Robertson \& Allen, 2015).

Most carapids are known to have speciesspecific host associations (Gustato, Villari, \& Villani; 1979; Parmentier, Mercier, \& Hamel, 2006; Smith, Tyler, \& Feinberg, 1981; Trott \& Trott, 1972). Although, several ex-situ studies have demonstrated that some species can associate with hosts in which they had never been found before in the wild (Parmentier, Mercier, \& Hamel, 2006; Trott, 1970; Trott, 1981). Given this, different fish species can use the same hosts; however, it seems that different fish species usually do not co-occur in the same individual host (Parmentier \& Vandewalle, 2005). In some areas, it has been observed a certain degree of segregation and specialization between co-occurring fish species regarding the use of some specific hosts; for example, in the Indo-West Pacific, C. mourlani restricts their occurrence to starfishes and other invertebrate species that are not used by other sympatric fishes (Parmentier \& Vandewalle, 2005). Multiple con-specific infestation events also have been observed, mainly in Indo-West Pacific sea stars and sea cucumbers (Meyer-Rochow, 1977; Parmentier \& Vandewalle, 2005), even in the ETP (Castro-Aguirre et al., 1996); and the affected individuals appear to be randomly distributed to other inhabited or uninhabited conspecific hosts (Meyer-Rochow, 1977; Parmentier \& Vandewalle, 2005). Such aggregations may have a reproductive connotation, considering that carapid fishes have a highly derived communication system that should allow a species-specific recognition (Parmentier \& Vandewalle, 2005). Therefore, the use and 
suitability of a specific host depend, in addition to its occurrence and relative abundance within the distributional range of the fish, to the degree of protection (shelter) that the host provides (or can provide), the availability of food resources (directly provided or not by the host), as weel as some colonization impediments (i.e., host size relative to fish size and/or other mechanical and/or chemical limitations imposed by the host). Moreover, it may be affected by the occurrence of other sympatric fish species, the availability of possible hosts, seasonal events (such as reproductive aggregations) and the occurrence and availability of carapid planktonic eggs and vexillifer larvae (Parmentier \& Vandewalle, 2005; Parmentier, Mercier, \& Hamel, 2006).

In this study we report the occurrence of the Star pearlfish Carapus mourlani within three previously unknown hosts in the ETP: the sea stars Nidorellia armata (Gray, 1840), Valvatida, Oreasteridae, Phataria unifascialis (Gray, 1840), Valvatida, Ophidiasteridae, and the sea cucumber Stichopus horrens Selenka, 1867, Synallactida, Stichopodidae; supported by material collected from the North Pacific coast of Costa Rica. At the same time, some ecological implications and considerations regarding such symbiotic relationships are raised and discussed. Additional morphometric and meristic data for the fish and the echinoderms are also provided and discussed. The information herein provided not only increase our knowledge about the ecology of these species, both fish and echinoderm, reporting new symbiotic associations but also help us to better know the diversity of such groups by providing additional morphological information and updated data on distribution that allows a better determination at the regional level.

\section{MATERIALS AND METHODS}

Echinoderms were manually collected by SCUBA diving or snorkeling at depths between 0 and $20 \mathrm{~m}$ in a total of 25 localities distributed along the coastline and the marine sector of the Área de Conservación Guanacaste (ACG), Costa Rica (Fig. 1) (details in Chacón-Monge, Azofeifa-Solano, Alvarado, \& Cortés, 2021). Fieldwork was carried out from July 2018 to August 2019 as part of a multi-institutional inventorying and monitoring program on the ACG developed and driven by the Sistema Nacional de Áreas de Conservación (SINAC), the Universidad de Costa Rica (UCR), and

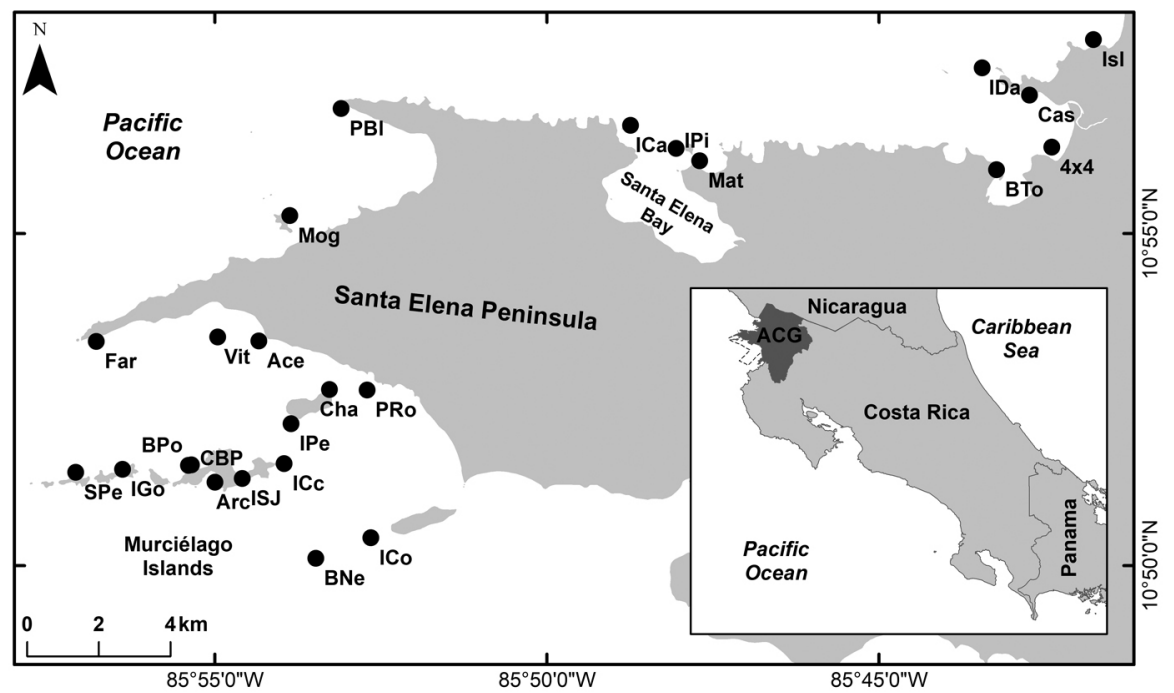

Fig. 1. Echinoderms sample sites at the North Pacific of Costa Rica, explored during five field surveys of the BioMar-ACG project. Modified from Chacón-Monge et al., (2021). Published with permission. 
the Guanacaste Dry Forest Conservation Fund (Cortés, 2017; Cortés \& Joyce, 2020). Research permits (R-SINAC-PNI-SE-002-2018 and R-SINAC-ACG-PI-004-2019-BIOMAR) were provided by the SINAC.

Specimens collected were labeled and placed in plastic bags separated into groups by locality and taxonomic affinity (i.e, species or morpho-species). Then, samples were transferred into seawater-filled buckets/trays to the laboratory and anesthetized with different seawater-menthol, -magnesium chloride, and/ or -alcohol (ethanol) solutions (Chacón-Monge et al., 2021). These different solutions were employed considering their availability, the relative size of the specimen and their taxonomic group, as well as previous observations regarding the effectiveness of each solution for each particular case (Chacón-Monge et al., 2021; Solís-Marín et al., 2014). For example, to warrant the adequate relaxation, fixation, and preservation of the samples, undesirable reactions as a natural response to alien-harsh solutions must be avoided (i.e. body-, organ-, appendage-retraction, autotomy, evisceration, etc.). In this regard, echinoderms belong to a relatively ancient phyllum, highly specialized in the marine life. That is reflected in the extended absence of complex osmoregulatory organs (Diehl, 1986; Pawson, 2007). Furthermore, whit the exception of the internal madreporite(s) plate(s) of the water vascular system of Holothuroidea, all of the extant echinoderm classes experiment an active interchange and direct communication to the surrounding seawater. The time to reach the specimen relaxation varies from sample to sample, and depends on the species/individualspecific tolerance and response through the narcotization process, as well as on the chemical quality, among others. At a larger ratio of soft-sensitive tissue and exposed area, there is more interaction with the surrounding solution, thus, small and thin body-layer specimens (relative to species) must not need too much time (i.e. 3-5 hours) or high concentrations of those solutions in their trays to get relaxed. In general medium- $(>6 \mathrm{~cm})$ as large-size $(>15$ $\mathrm{cm}$ ) holothuroids requires the injection of alcohol through their anus to the fixation of the internal tissues and organs after relaxation, which could be delated by their apnea ability. Most sea cucumber, and large samples of almost all species were lead for a half-day (12 h) in darkness until their death, after progressive incorporation of those narcotic solutions.

Once the specimens were completely anesthetized, they were checked for the presence of commensal/parasitic fishes (while they were in the buckets/trays, the fishes occupying the internal cavities of the echinoderms tend to seek the exterior due to the effect of the anesthetic, and by the decrease in the oxygen concentration in the water; this made it easy to detect them after a quick visual sample inspection). Echinoderm samples hosting fishes were photographed and measured (Table 1) with an analog caliper. All samples were fixed and preserved in ethanol $70 \%$. In the laboratory, some large specimens, and those for which the presence of commensal/parasitic fishes was detected, were dissected to looking for additional fishes. Echinoderms were identified based on specialized taxonomic literature for the region (Borrero-Pérez \& Vanegas-González, 2020; Massin, Zulfigar, Tan, \& Rizzal, 2002; Solís-Marín, Arriaga-Ochoa, Laguarda-Figueras, Fontana-Uribe, \& Durán-González, 2009; Solís-Marín et al., 2014; Martín-Cao-Romero, Solís-Marín, Laguarda-Figueras, \& BuitrónSánchez, 2017; Woo, 2013; Woo, 2018; Woo, Zulfigar, Tan, Kajihara, \& Fujita, 2015); the morphological data and terminology employed follow Solís-Marín et al. (2014), Woo (2013), and Woo et al. (2015). Fishes were identified following Nielsen, Cohen, Markle, and Robins (1999), and Robertson and Allen (2015); the morphological data and terminology employed follow Markle and Olney (1990), and Nielsen et al. (1999). Morphometric measurements (Table 2) from all fishes were taken with a digital caliper, after fixation in formalin $10 \%$, and preserved in ethanol $70 \%$. Counts were taken following Markle and Olney (1990), on three specimens that were cleared and stained following Taylor and Dyke (1985). Species valid 
names, authorities, and year of description follows the WoRMS Editorial Board (2021), for invertebrates, and Fricke, Eschmeyer, and Fong (2021), for fishes. Infested echinoderms, as well as two fish specimens from different hosts, were photographed and used as vouchers for tissue samples (preserved in ethanol $96 \%$ ). Samples from all vouchered specimens were sent to the Center for Biodiversity Genomics, at the University of Guelph, for DNA sequencing and barcoding (Cortés \& Joyce, 2020). Both echinoderm (ECH) and fish (FIS) voucher specimens were deposited at the Museum of Zoology of the Universidad de Costa Rica (MZUCR; see details below, "Material examined").

\section{RESULTS}

A total of 497 echinoderms, representing 60 species [including seven sea star species represented by 56 individuals, and 30 sea cucumber species represented by 192 individuals (see Chacón-Monge et al., 2021, for details)], were collected. Of these, only three specimens, including two sea stars and one sea cucumber were found to host carapid fishes. The two sea stars were identified as Nidorellia armata (one host specimen, Fig. 2B, from a total of seven conspecific samples) and Phataria unifascialis (one host specimen, Fig. 2C and Fig. 2D, from a total of 15 conspecific samples), respectively, whereas the sea cucumber was identified as Stichopus horrens (one host specimen, Fig. 2E, Fig. 3, Fig. 4, Fig. 5, Fig. 6, Fig. 7, from a total of two conspecific samples). The sea stars were found to host one carapid fish each, whereas the sea cucumber was found to host a multiple infestation (Table 1, Fig. 2E). Most fishes (12) were detected in the field; dissections on the laboratory allowed the detection of an additional fish in the infested specimen of $S$. horrens (Fig. 3), totalizing 13 individuals. All fishes were identified as C. mourlani and were considered as commensal, see details below. 
TABLE 2

Morphometric (M) and meristic (C) data from examined specimens of Carapus mourlani from ACG, Costa Rica, and comparative data from material from the Indo-West Pacific (Markle \& Olney, 1990). Measurements expressed as proportions of the head length; head length expressed as proportion of the total length; total length in $\mathrm{mm}$. ND=No Data.

\begin{tabular}{|c|c|c|c|c|}
\hline \multirow{3}{*}{ Measurements/Counts } & \multirow{2}{*}{\multicolumn{2}{|c|}{$\begin{array}{c}\text { Markle \& Olney (1990) } \\
\mathrm{n}=17(\mathrm{M}) / 41(\mathrm{C})\end{array}$}} & \multirow{2}{*}{\multicolumn{2}{|c|}{$\begin{array}{c}\text { This study } \\
\mathrm{n}=11(\mathrm{M}) / 3(\mathrm{C})\end{array}$}} \\
\hline & & & & \\
\hline & Min. & Max. & Min. & Max. \\
\hline Total length & 65.00 & 170.00 & 64.9 & 105.12 \\
\hline Body depth & 0.49 & 0.69 & 0.39 & 0.67 \\
\hline Head length* & ND & ND & 0.14 & 0.17 \\
\hline Head depth & 0.45 & 0.55 & 0.50 & 0.59 \\
\hline Head width & 0.30 & 0.50 & 0.34 & 0.49 \\
\hline Snout length & 0.16 & 0.19 & 0.17 & 0.21 \\
\hline Upper jaw lenght & 0.43 & 0.62 & 0.43 & 0.58 \\
\hline Lower jaw length & 0.44 & 0.58 & 0.41 & 0.57 \\
\hline Eye diameter & 0.15 & 0.22 & 0.17 & 0.26 \\
\hline Postocular lenght & ND & ND & 0.55 & 0.66 \\
\hline Interobital distance & 0.14 & 0.18 & 0.13 & 0.19 \\
\hline Prepectoral length & ND & ND & 0.98 & 1.09 \\
\hline Pectoral fin lenght & 0.33 & 0.47 & 0.34 & 0.52 \\
\hline Predorsal length & 1.57 & 1.92 & 1.62 & 1.91 \\
\hline Preanal length & 0.86 & 1.00 & 0.82 & 0.98 \\
\hline Pectoral-fin rays & 17 & 21 & 18 & 20 \\
\hline Anal-fin rays anterior to the origin of the dorsal fin & 18 & 25 & 19 & 23 \\
\hline Anal-fin rays to 31 st vertebra & 54 & 61 & 55 & 59 \\
\hline Dorsal-fin rays to 31 st vertebra & 35 & 41 & 35 & 39 \\
\hline Vertebrae to the origin of the dorsal fin & 11 & 14 & 12 & 13 \\
\hline Vertebrae to the origin of the anal fin & 2 & 4 & 2 & 3 \\
\hline Precaudal vertebra & 15 & 17 & 15 & 16 \\
\hline
\end{tabular}

\section{Hosts identification}

The specimen of $N$. armata (MZUCRECH 1629; Fig. 2B) was identified based on the following combination of observed external characters: disc pentagonal, relatively large, wide and robust, with five wide and short arms; abactinal surface convex with a wide papular area, surrounded by a reticulate pattern composed of polygonal plates, some with large, conical, and well developed black-purple spines, which contrast with the cream or lightbrown background surface; abactinal spines pentagonal-like arranged on the center of the disc and radially aligned on the arms; madreporite relatively large and irregular; marginal plates well developed. Actinal surface flat, covered by small granules and slightly rounded spines; actinal spines regularly distributed and slightly separated from each other, most of the same size, except those nearest to the mouth, whose are comparatively more elongated; inferomarginal plates with tiny spines, similar to those over the abactinal surface. Ambulacral and adambulacral plates similar to each other, bearing round and short spines; valvated pedicellariae present on the actinal surface, near to the mouth; centrally linked to the oblong ambulacral rows, over which runs biseriate ambulacral podia with sucker terminal discs.

The specimen of $P$. unifascialis (MZUCRECH 1834; Fig. 2C, Fig. 2D) was identified based on the following combination of observed external characters: disc pentagonal, relatively short, and reduced, with five trigonal and tapered arms. Papular area restricted to the 

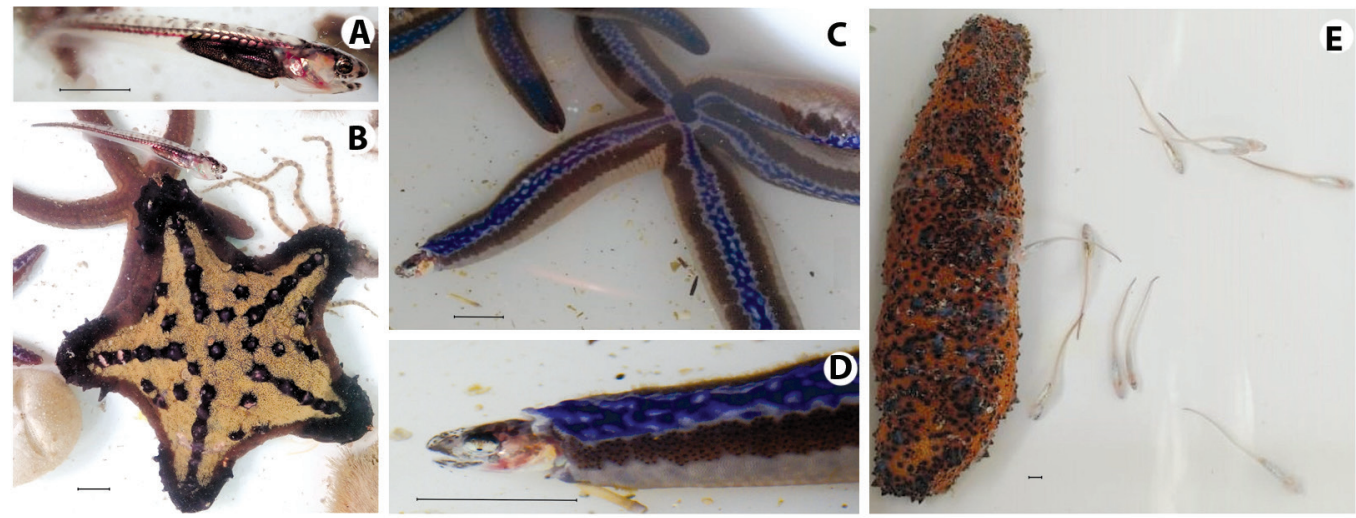

Fig. 2. Symbiosis between Carapus mourlani and their echinoderms hosts from samples collected in the North Pacific of Costa Rica during BioMar-ACG project. A): C. mourlani detail; B): Nidorellia armata and its unique carapid inquiline; C) Phataria unifascialis and its unique carapid inquiline; D): close-up of the tip of P. unifascialis arm, showing a C. mourlani going out from its ambulacral host. E): multiple infestation of C. mourlani in Stichopus horrens. All scales are $1 \mathrm{~cm}$.
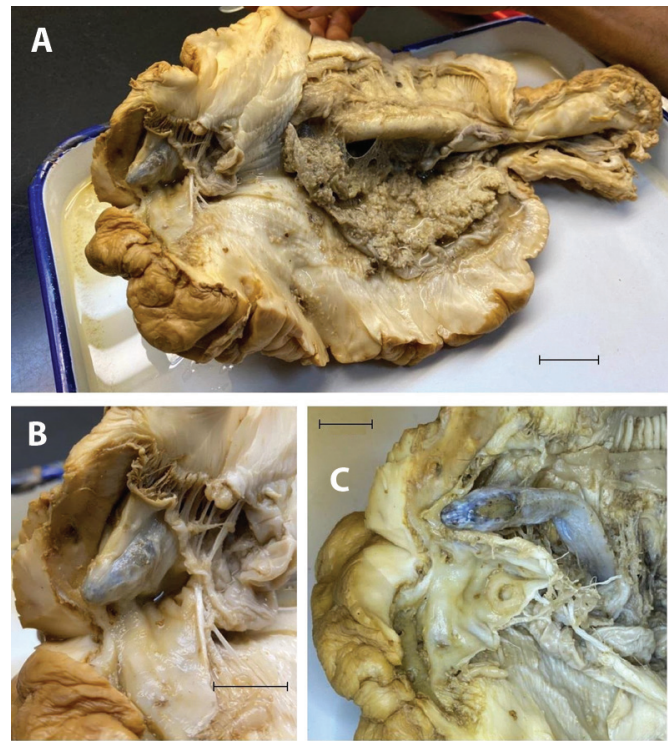

Fig. 3. Stichopus horrens dissection showing an additional Carapus mourlani. Scales $1 \mathrm{~cm}$. A): longitudinal slice from the anus to the mouth of $S$. horrens; B): protrusion of the $C$. mourlani head through cloaca epithelium; C): C. mourlani view after remove the epithelium cloaca at the side of the sphincter.

abactinal surface; as a single main papular line along the upper arm surface, and two small secondary rows at both sides of the main row. Anus located centrally on the disc; a single rounded madreporite with radial striations; three longitudinal rows of carinal plates along each arm. Both, the actinal and abactinal surface covered by granulation; granules are large and dense in the abactinal plates, while being small and spread in the papular area, granules of the actinal surface are rounded and spaced. The ambulacral rows have a single row of tapering ambulacral spines.

The specimen of $S$. horrens (MZUCRECH 1878; Fig. 2E, Fig. 3, Fig. 4, Fig. 5, Fig. 6 , Fig. 7) was identified based on the following combination of observed external and internal characters: body elongated, vermiform, subquadrangular in the cross-section, and robust; integument thick, with a firm and rough surface, and a slight mid-dorsal wrinkle. Background orange, dark brown, and yellowish, with tiny scattered white patches; dorsal- and ventrolateral papillae conspicuous, with dark purple-brown bases and white apex. Mouth oriented ventrally, with a crown of 20 peltate oral tentacles; oral opening surrounded by a ring of small papillae. Ventral sole (trivium) palecream and flat, with three ambulacral areas, the median row wider. Cuvierian tubules absent; anal teeth or papillae around the terminal cloaca absent; gonads into two tufts, attached to the dorsal mesentery. Ossicles in the bivium and trivium surface as tables, branched rods, and $\mathrm{C}$-shaped bodies mainly, while those of the dorsal papillae being as high-spired tables 

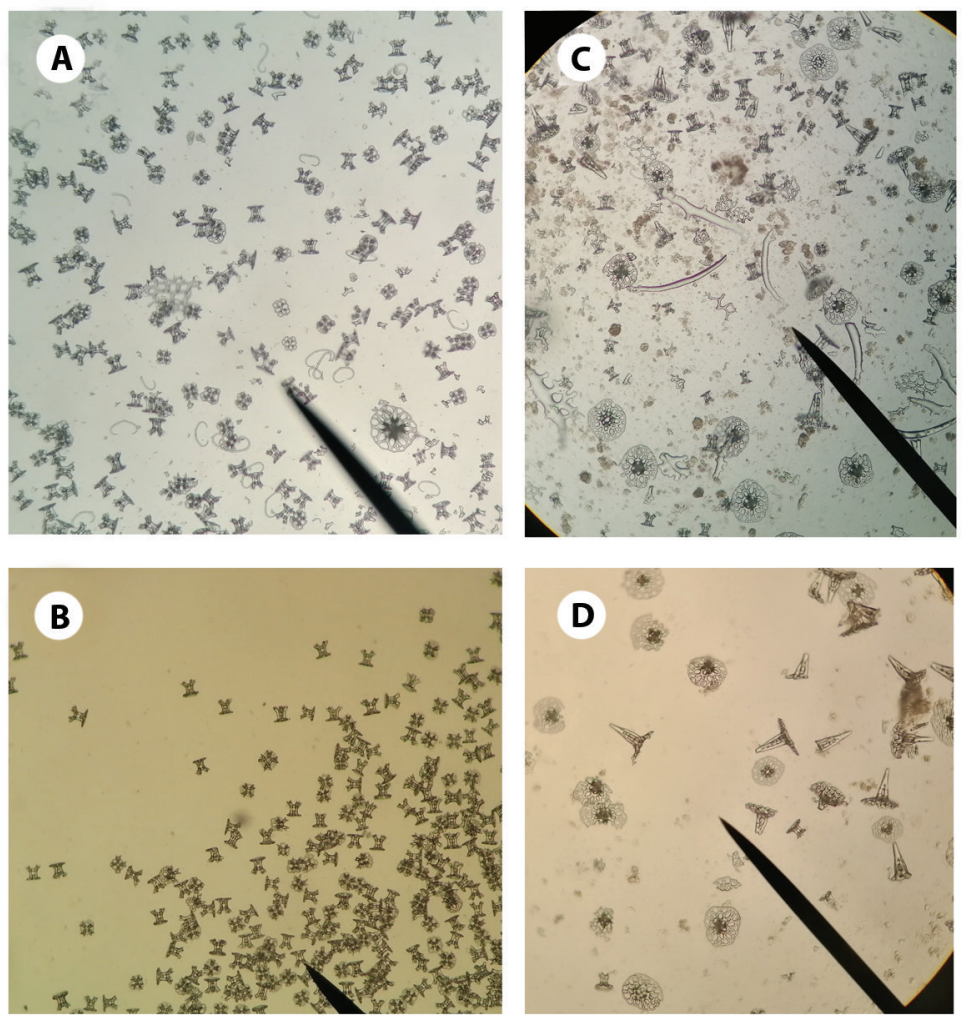

Fig. 4. Ossicles from Stichopus horrens bivium tissue sample. A): tables, C and S body shape; B): tables; C) and D): tack-liked tables.
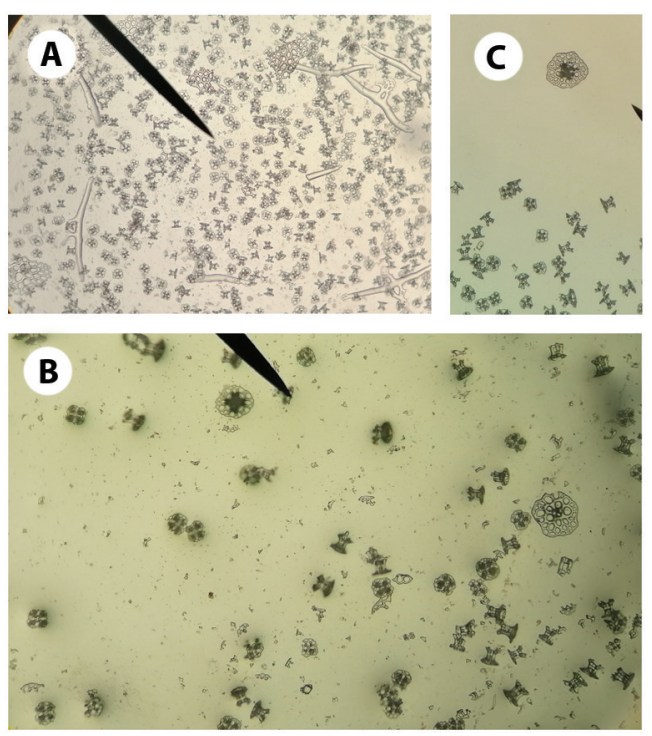

Fig. 5. Ossicles from Stichopus horrens trivium tissue sample. A): tables, rods and perforate plates; B) and C): approach to tables and perforate plates. (tack-liked tables) (Fig. 4, Fig. 5); and fusiform (spindle-like) ossicles in the tentacles (Fig. 6).

\section{Pearl fish identification}

The fishes (MZUCR-FIS 3313-3315) were identified based on the following combination of observed external characters: body elongate, short and compressed; translucent, silvery to coppery on cheek and abdomen, with many star-shaped dark blotches on the head and the dorsal portion of the body; the tip of snout without fleshy flaps. Upper jaw extending beyond the posterior edge of the eye, free from head (i.e., not bound to the side of the head by skin), with one or two large, conical and curved teeth and an outer row of small, sharp, and slender teeth; lower jaw with a patch of small teeth at the front, before an external row of large, curved and conical 

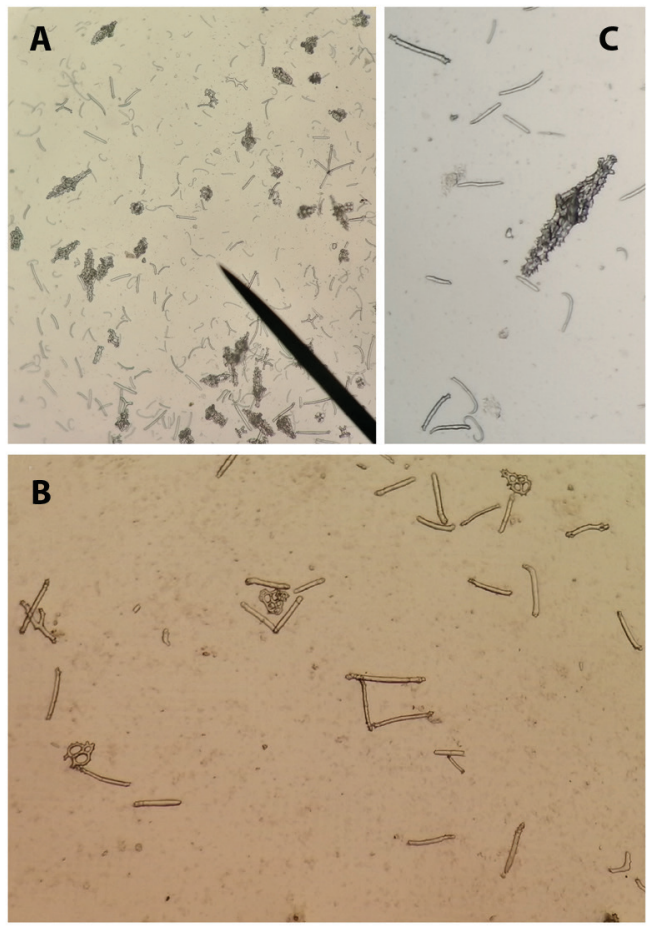

Fig. 6. Ossicles from $S$. horrens tentacle tissue sample. A): rods, $\mathrm{C}$ and $\mathrm{S}$ body shape, fusiform (spindle-like); B) rods and perforate plates magnification; C): fusiform ossicle (spindle-like ossicle) magnification.

teeth, and three to five rows of small conical teeth inside those; roof of the mouth with two or three large canines at the front, and a band of short conical teeth on each side. Gill opening extending above the mid-side; gill membranes not united below; gill rakers well developed. Swim bladder constricted, forming two chambers, without a thin terminal membrane or bulb; pectoral fin well developed, two to three times the head length, with 17-21 rays; anus and origin of the anal fin located before the base of the pectoral fin; dorsal fin origin located well behind the origin of the anal fin; dorsal and anal fins confluent with caudal fin; and tail long and slender. Additional morphometric and meristic data for fish specimens are provided in Table 2 .

Material examined: MZUCR-ECH 1629/ MZUCR-FIS 3313: Isla Pitahaya, Bahía Santa Elena, Guanacaste, Costa Rica, 10 ${ }^{\circ} 56^{\prime} 08^{\prime \prime} \mathrm{N}$, $85^{\circ} 48^{\prime} 06^{\prime \prime} \mathrm{W}, 8 \mathrm{~m}$ depth (rocky reef), collected by J. L. Chacón-Monge, C. Mora-Barboza, Y. Vega \& G. Ampié on 8-August-2018. MZUCRECH 1834/MZUCR-FIS 3314: Mogotes, Isla Negritos, Playa Blanca, Península de Santa Elena, 1055'08" N, 85'53'56" W, 9 m depth (rocky reef), collected by J. L. Chacón-Monge, C. Mora-Barboza, Y. Vega \& G. Ampié on 30-July-2019. MZUCR-ECH 1878/MZUCR-FIS 3315: Bajo Pochote, Isla San José, Islas Murciélago, Guanacaste, Costa Rica, $10^{\circ} 51^{\prime} 22^{\prime \prime} \mathrm{N}, 85^{\circ} 55^{\prime} 24^{\prime \prime} \mathrm{W}, 11-15 \mathrm{~m}$ depth
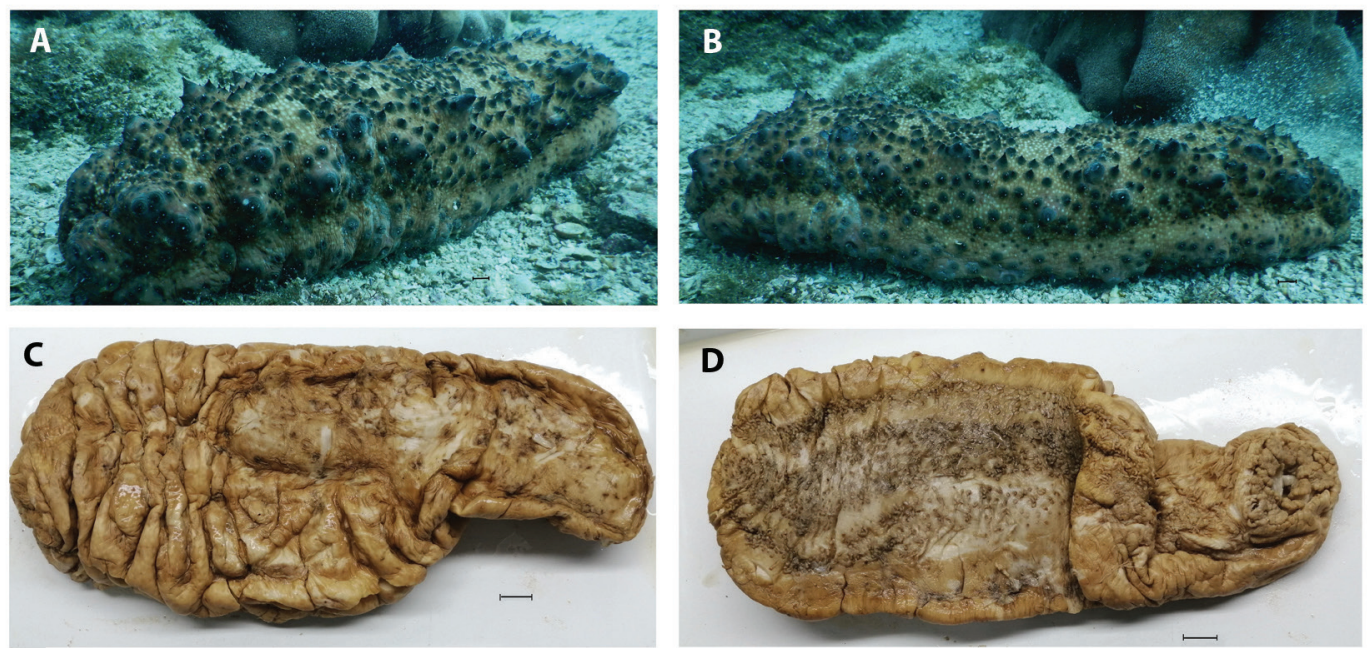

Fig. 7. S. horrens: A) and B): on their natural habitat, and C) and D): preserved specimen, scales are $1 \mathrm{~cm}$. 
(compound reef), collected by J. L. ChacónMonge, C. Mora-Barboza, Y. Vega \& G. Ampié on 31-July-2019.

\section{DISCUSSION}

Carapus mourlani is widely distributed in the tropical Indo-Pacific Ocean, from East Africa, through Oceania and Hawaii, to southern Central America and Ecuador (Glynn et al., 2008; Markle \& Olney, 1990; Robertson \& Allen, 2015) and this distribution is thought to be related, among other factors (e.g., currents patterns, water temperature, food availability, etc.), to the co-occurrence of its preferred hosts (i.e., sea stars and sea cucumbers in general) (Machida, 1989). In the central and western Indo-Pacific Ocean, C. mourlani is known to inhabit the sea stars Acanthaster planci (Linnaeus, 1758), Choriaster granulatus Lütken, 1869, Culcita novaeguineae Müller \& Troschel, 1842 and Pentaceraster cumingi (Gray, 1840), the sea cucumbers Actinopyga mauritiana (Quoy \& Gaimard, 1834), Holothuria (Metriatyla) scabra Jaeger, 1833, Bohadschia argus Jaeger, 1833, Stichopus chloronotus Brandt, 1835, and Stichopus variegatus Semper, 1868 (Glynn et al., 2008; Markle \& Olney, 1990; Meyer-Rochow, 1979). Records of the species in the ETP are restricted to the sea hare D. auricularia and the sea cucumber I. fuscus (Glynn et al., 2008). The identification of two new sea stars and one new sea cucumber as hosts for C. mourlani in the ETP support the observation that the Star pearlfish prefer species of echinoderms as hosts and that they can found shelter in species that are not hosting other fishes, since none of these species have been reported as hosts for the other sympatric commensal or parasitic carapids (Markle \& Olney, 1990; Parmentier, Mercier, \& Hamel, 2006; Robertson \& Allen, 2015). Moreover, the record within $N$. armata, P. unifascialis, and $S$. horrens broadens the list of echinoderm hosts for this carapid fish, considering the whole distribution range of the species, to 13 different taxa, including six sea stars and six sea cucumbers.
Nidorellia armata and P. unifascialis are widely distributed in the ETP, from the Gulf of California to Perú (Borrero-Pérez \& Vanegas-González, 2020; Martín-Cao-Romero et al., 2017; Solís-Marín et al., 2014), however, they had not been confirmed yet as hosts of C. mourlani. This could be partly due to the lack of studies examining in detail such associations, the omission of such information in studies inventorying the echinoderm fauna at different local and regional scales, and the little or no interaction and exchange of information between specialists working with both taxonomic groups (Parmentier, Lanterbecq, \& Eeckhaut, 2016; Parmentier, Mercier, \& Hamel, 2006). We also find interesting the fact that some confirmed hosts of $C$. mourlani, such as the sea stars $A$. planci and $P$. cumingi (Glynn et al., 2008; Markle \& Olney, 1990), which occur in the North Pacific of Costa Rica have not been reported as hosts for this species in the ETP. In this regard, we could think that (possible or potential) host species with large and flexible body cavities [as those cited above, as well as other sea stars and sea cucumbers used as hosts by $C$. mourlani in other latitudes, some of which are also present in the study area (Chacón-Monge et al., 2021)] could be more suitable than -and even preferred- over other small and rigid species, which have comparatively smaller body cavities. However, as could be derived from our research, this is not the case. The reasons for this could be the same as those mentioned before, and/or correspond to intrinsic biological/ecological (e.g., physiological, mechanical, ethological, ontogenetic, among others) and environmental differences, including different or additional selective pressures and/or adaptive advantages/ disadvantages, between the different populations and species involved through their respective distributional ranges (Machida, 1989; Parmentier, Lanterbecq, \& Eeckhaut, 2016; Parmentier, Mercier, \& Hamel, 2006; Parmentier \& Vandewalle, 2005).

As C. mourlani, the distribution of $S$. horrens encompasses the tropical Indo-Pacific Ocean, from East Africa, through Oceania 
and Hawaii, to part of the ETP (Cortés, 2012; Glynn et al., 2008; Massin et al., 2002; Woo, 2013; Woo, 2018; Woo, Zulfigar, Tan, Kajihara, \& Fujita, 2015); however, as in the previous cases, this is the first published record suggesting a specific association between both species. On the other hand, despite $S$. horrens had already been reported from Isla del Coco, this is the first confirmed record of occurrence of the species within Costa Rican coastal waters (Alvarado, 2010; Alvarado et al., 2017; Chacón-Monge et al., 2021; Cortés, 2012). In other latitudes, there are records of associations between Stichopus and C. mourlani (Glynn et al., 2008), however, such records refer to $S$. variegatus sensu lato. This name, however, is not currently accepted as valid (see the WoRMS Editorial Board, 2021) and, as cited by Glynn et al., (2008), it may correspond to one of the following two species: Stichopus herrmanni Semper, 1868, Stichopus naso Semper, 1868 , or even to $S$. horrens, with which was synonymized, in part (WoRMS Editorial Board, 2021). Given this, it is necessary to confirm the taxonomic identity of the hosts reported by Glynn et al. (2008) to know if the association described here correspond, in fact, to the first report of a specimen of $S$. horrens hosting specimens of $C$. mourlani. Additionally, we herein report for the first time, the presence of fusiform (spindle-like) ossicles in the tentacles of $S$. horrens, as previously reported for other congeneric species (Woo, 2013; Woo, 2018; Woo et al., 2015).

The morphological identification of the C. mourlani's hosts, was tried to be corroborated by molecular analysis (unpublished data). Unfortunately, for N. armata and P. unifascialis, there is no nucleotide information available to compare our vouchers, and the best molecular identity matches (i.e., have similar/compatible COI sequences) were Iconaster longimanus from Singapore (81.61\%) and Linckia laevigata from Indonesia $(86.47 \%)$, respectively (from sequences available for comparison in BLAST, https://blast.ncbi.nlm.nih.gov). The sequencing of the $S$. horrens host voucher was no successful. Nevertheless, we can confirm indirectly its identification from the other con-specific specimen (not found as C. mourlani host), which is 98.16\% similar/compatible (COI sequences) to $S$. horrens vouchers from China (from samples available for comparison in BLAST https:// blast.ncbi.nlm.nih.gov).

We can also confirm our hosts' identification by discarding. First, both sea star species belongs to the Valvatida Order, which means that dermo-skeletal formations as granules, spines, plates, and the valvate pedicellariae have diagnostic significance (Solís-Marín et al., 2014). Comparatively, there is no other sea star that could be confused with $N$. armata within the Oreasteridae family (those valvatids with large, robust, or projected marginal plates; whose actinal and abactinal plates could be rounded or polygonal, but never paxilliform) in the ETP (Solís-Marín et al., 2013; Solís-Marín et al., 2014). Concerning its distribution, in Costa Rica, P. unifascialis could be confused with Pharia pyramidata (Gray, 1840); this genus also belongs to the Ophidiasteridae family (those valvatids with no prominent marginal plates, body densely covered by granules, small disc and a wide abactinal popular area; Solís-Marín et al., 2014), but it has been pointed out that $P$. unifascialis differs from other ophidiasterids by the following combination of characters: 1) popular area restricted in one longitudinal row along the radius, and two small papular rows that can reach to half or less the longitude of the main row, at both sides of the main popular area, 2) three carinal plates rows along the radius, and 3) only one row of ambulacral spines, wider in the base and tapering (Martín-Cao-Romero et al., 2017). Finally, there is only two Stichopodidae species registered for the ETP: I. fuscus, and S. horrens (Solís-Marín et al., 2013), both share the presence of ossicles like tables, rosettes, rods, or even " $C$ " and " $S$ " -shaped bodies, and large gonads in two tufts (Deichmann, 1958; SolísMarín et al., 2009; Woo, 2018) as observed in the dissected host. However, the tack-liked tables from papillae and fusiform ossicles in tentacles have never been found in I. fuscus and 
should be considered to be part of the diagnosis of $S$. horrens.

On the other hand, fish's morphometric and meristic data match well with those reported from specimens collected in the IndoPacific region, sensu Markle and Olney (1990) and Nielsen et al. (1999), as well as from comparative data provided by Robertson and Allen (2015), based on collections and material from other localities within the ETP. These results suggest that there is no morphological differentiation (at least in terms of the characters herein examined) between the populations of the Indo-West Pacific and the ETP. A preliminary molecular analysis (data not provided/ discussed here) revealed that the samples/data obtained/generated in this study (i.e., COI sequences for two $C$. mourlani individuals) are 98-100\% similar/compatible with sequences available in GeneBank (https://www.ncbi.nlm. nih.gov/genbank/) from con-specific specimens collected in Micronesia. Such results suggest a low genetic structuring (i.e., high homogeneity and gene flow between populations), potentially explained by the high dispersal capacity of the rafting eggs and larval stages of these fishes (Markle \& Olney, 1990; Parmentier \& Vandewalle, 2005). These observations make sense, considering that most species of the family also present wide distributions, at a global scale, with fairly conserved populations in terms of most of their morphological (external and internal) features (Markle \& Olney, 1990; Nielsen et al., 1999). This can be reinforced, even, by some intraspecific ethological patterns, as the preference of phylogenetically close or ecologically similar hosts, with relatively wellknown interspecific differences (Markle \& Olney, 1990; Parmentier, Mercier, \& Hamel, 2006; Parmentier \& Vandewalle, 2005).

Despite the overall low frequency of infestation found in this study, which is comparable with the results of previous inventories in nearby areas for other species, e.g., the Gulf of California, Mexico (Castro-Aguirre et al., 1996) and the mainland of Ecuador (Parmentier, Mercier, \& Hamel, 2006), $50 \%$ of the collected specimens of $S$. horrens were found to shelter carapid fish. Moreover, since eleven fish were found inside this sea cucumber, it should be considered as a multiple infestation event. To the authors' best knowledge, multiple infestation events in the ETP are relatively rare and have been recorded only for the species C. dubius inside specimens of Megapitaria squalida (G. B. Sowerby I, 1835), for which up to 5 fishes have been reported in a single host (Castro-Aguirre et al., 1996). Multiple infestations have been reported before in other regions of the world, in other echinoderm hosts, e.g., within the sea star $C$. novaeguineae, and the sea cucumber B. argus (Parmentier, Lanterbecq, \& Eeckhaut, 2016; Parmentier \& Vandewalle, 2005); moreover, such behavior also has been observed and induced in specimens kept in captivity (Meyer-Rochow, 1977; Meyer-Rochow, 1979; Parmentier \& Vandewalle, 2005). Previous authors (e.g., Trott, 1970; Parmentier, Colleye, \& Lecchini, 2016; Parmentier, Fine, Vandewalle, Ducamp, \& Lagardère, 2006; Parmentier \& Vandewalle, 2005) have suggested that these multiple infestation events have reproductive implications, however, this has not been fully demonstrated. In this study, all the eleven fish found inside $S$. horrens were adults, of these eight were ovigerous females, and three were mature males. The presence of these reproductive specimens inside this host could offer support in favor of a possible hypothesis of reproductive aggregations; however, detailed studies are required (both at the physiological and ethological levels) in order to corroborate this. On the other hand, the nonrandom occurrence of multiple con-specific infestations, the aggrupation of reproductive specimens and observations on sex ratio, and the restricted use of some hosts but no others of some species in the presence of other carapid fish, could support the hypothesis of the evolution of acoustic signals in these fishes for the interspecific differentiation, which can help to avoid interspecific conflicts (Parmentier, Colleye, \& Lecchini, 2016; Parmentier \& Vandewalle, 2005). The generalistic pattern of host selection by C. mourlani could be inferred, in part, given its feeding behavior (described 
as a generalist carnivorous that feeds outside its hosts; Parmentier, Mercier, \& Hamel 2006; Robertson \& Allen, 2015), as well as the apparently wide "host adaptive landscape" (Zaman et al., 2014) explored by this species through its equally wide geographical distribution range (Parmentier, Lanterbecq, \& Eeckhaut, 2016).

Ethical statement: authors declare that they all agree with this publication and made significant contributions; that there is no conflict of interest of any kind; and that we followed all pertinent ethical and legal procedures and requirements. All financial sources are fully and clearly stated in the acknowledgements section. A signed document has been filed in the journal archives.

\section{ACKNOWLEDGMENTS}

We thank Frank Joyce and Cristian MoraBarboza for their support before and during field sampling. We also thank the administrative staff of the CIMAR, the School of Biology and the Museum of Zoology, CIBET, of the UCR, for the support and materials, equipment and workspace provided during the execution of this work. To the Sistema Nacional de Áreas de Conservación (SINAC) and the Ministerio de Ambiente y Energía (MINAE) for facilitating the research and collection permits. To the ACG, the Guanacaste Dry Forest Conservation Fund and the University of Costa Rica for the financing granted under the BioMar-ACG project (808-B9-508). We also thank to the scientific editors of this volume for their invitation to colaborate and finally, thanks to the anonymous reviewers whose comments and suggestions help to improve and clarify this manuscript.

\section{RESUMEN}

\section{Nuevos hospederos y datos morfológicos para el Pez perla estrella Carapus mourlani (Ophidiiformes: Carapidae) a partir de recolectas realizadas al norte de la costa Pacífico de Costa Rica}

Introducción: La familia Carapidae está compuesta por alrededor de 40 especies de peces marinos, presentes en hábitats costeros alrededor de todo el mundo. Se incluyen dentro de esta familia algunas especies de vida libre, no obstante, la mayoría de carápidos son inquilinos oportunistas o parásitos de algunos grupos de invertebrados marinos, incluyendo varias especies de equinodermos. En el Pacífico Tropical Oriental (PTO), se sabe relativamente poco sobre la biología de estos peces, así como de las diversas asociaciones existentes y de los hospederos utilizados.

Objetivo: En este trabajo reportamos la ocurrencia del Pez perla estrella Carapus mourlani en tres nuevos hospederos: las estrellas de mar Nidorellia armata y Phataria unifascialis, y el pepino de mar Stichopus horrens. También se discuten algunas implicaciones y consideraciones ecológicas relacionadas a estas asociaciones simbióticas. Además, se proveen y discuten datos morfométricos y merísticos de los peces y sus hospederos.

Métodos: Se realizaron recolectas de equinodermos, entre 2018 y 2019 , en un total de 25 localidades distribuidas al norte de la costa Pacífico de Costa Rica, los cuales fueron cuidadosamente revisados en búsqueda de peces comensales/parásitos. Los equinodermos y los peces fueron identificados y caracterizados de acuerdo con la literatura especializada.

Resultados: Se recolectaron y examinaron un total de 497 equinodermos, incluyendo alrededor de 60 especies, de los cuales solo tres individuos-especies estuvieron ocupados por peces comensales/parásitos.

Conclusiones: La lista de hospederos equinodermos de $C$. mourlani a lo largo de su ámbito de distribución geográfico llega a 12 especies (seis estrellas de mar y seis pepinos de mar), lo cual podría ser un reflejo de su amplia distribución geográfica, de sus hábitos de alimentación generalistas y de su comportamiento oportunista en lo relativo al uso de hospederos.

Palabras clave: Pacífico Tropical Oriental; América Central; Área de Conservación Guanacaste; simbiosis; Nidorellia armata; Phataria unifascialis; Stichopus horrens.

\section{REFERENCES}

Alvarado, J. J. (2010). Isla del Coco (Costa Rica) Echinoderms: State of knowledge. In L.G. Harris, S.A. Böttger, C.W. Walker, \& M.P. Lesser (Eds.), Echinoderms: Durham. Proceedings 12th International Echinoderm Conference (pp. 103-113). Leiden, Netherlands: CRC Press, Taylor \& Francis Group, Balkema.

Alvarado, J. J., Chacón-Monge, J. L., Solís-Marín, F. A., Pineda-Enríquez, T., Caballero-Ochoa, A. A., Solano Rivera, S., \& Romero-Chaves, R. (2017). Equinodermos del Museo de Zoología de la Universidad de Costa Rica. Revista de Biología Tropical, 65(Supplement 1), S272-S287.

Borrero-Pérez, H., \& Vanegas-González, M. J. (2020). Riqueza, composición y distribución de los 
equinodermos de los Riscales y Morros del norte del Cocó, Pacífico Colombiano. In L. Chasqui (Ed.), Biodiversidad de los arrecifes rocosos (riscales y morros) del Pacífico Norte Chocoano (No. 116, pp. 232-282). Santa Marta, Colombia: Serie Publicaciones Generales de INVEMAR.

Castro-Aguirre, J. L., García-Domínguez, F., \& Balart, E. F. (1996). Nuevos hospederos y datos morfométricos de Encheliophis dubius (Ophidiiformes: Carapidae) en el Golfo de California, México. Revista de Biologia Tropical, 44(2), 753-756.

Chacón-Monge, J. L., Azofeifa-Solano, J. C., Alvarado, J. J., \& Cortés, J. (2021). Área de Conservación Guanacaste echinoderms, North Pacific of Costa Rica. Revista de Biología Tropical, 69(Supplement 1), S487-S500

Cortés, J. (2012). Marine biodiversity of an Eastern Tropical Pacific oceanic island, Isla del Coco, Costa Rica. Revista de Biología Tropical, 60(Supplement 3), S131-S185.

Cortés, J. (2017). Marine biodiversity baseline for Área de Conservación Guanacaste, Costa Rica: published records. ZooKeys, 652, 129-179.

Cortés, J., \& Joyce, F. (2020). BioMar-ACG: A successful partnership to inventory and promulgate marine biodiversity. Biotropica, 52, 1104-1107.

Deichmann, E. (1958). The Holothurioidea collected by the Velero III and $I V$ during the years 1932 to 1954 Part II. Aspidochirota. Allan Hancock Pacif. Expeditions, 11, 249-349.

Diehl, W. J. (1986). Osmoregulation in echinoderms. Comparative Biochemistry and Physiology, 84(2), 199-205.

Fricke, R., Eschmeyer, W. N., \& Fong, J. D. (2021). Genera/Species by Family/Subfamily. Eschmeyer's Catalog of Fishes. http://researcharchive.calacademy.org/ research/ichthyology/catalog/SpeciesByFamily.asp

Fricke, R., Eschmeyer, W. N., \& Van der Laan, R. (2021). Genera, Species, References. Eschmeyer's Catalog of Fishes. http://researcharchive.calacademy.org/ research/ichthyology/catalog/fishcatmain.asp)

Glynn, P. W., Enochs, I. C., McCosker, J. E., \& Graefe, A. N. (2008). First record of a Pearlfish, Carapus mourlani, inhabiting the Aplysiid opisthobranch mollusc Dolabella auricularia. Pacific Science, 62, 593-601.

González, M. J. V., \& Borrero-Pérez, G. H. (2020). First records and new information on the associations of echinoderms with other phyla in the rocky reefs of northern Chocó, Colombian Pacific. ZooKeys, 921, $1-22$.

Gustato, G., Villari, A., \& Villani, G. (1979). Ulteriori dati sul comportamento di Carapus acus (Gadiformes,
Ophidiodei). Bollettino della Società dei naturalisti in Napoli, 88, 535-547.

Machida, Y. (1989). New distribution records of the Pearlfish, Carapus mourlani, with notes on its Morphometry. Japanese Journal of Ichthyology, 36, 363-368.

Markle, D., \& Olney., J. (1990). Systematics of the pearlfish (Pisces: Carapidae). Bulletin of Marine Science, 47, 269-410.

Martín-Cao-Romero, C., Solís-Marín, F. A., LaguardaFigueras, A., \& Buitrón-Sánchez. B. E. (2017). Phataria unifascialis (Valvatida: Ophidiasteridae) from the Eastern Pacific: Redescription and skeletal morphology. Revista de Biologia Tropical, 65(Supplement 1), S258-S271.

Massin, C., Zulfigar, Y., Tan Shau Hwai, A., \& Rizzal, S. (2002). The genus Stichopus (Echinodermata: Holothuroidea) from the Johore Marine Park (Malaysia) with the description of two new species. Biologie, $72,73-99$.

Meyer-Rochow, V. (1977). Comparison between 15 Carapus mourlani in a single Holothurian and 19 C. mourlani from Starfish. Copeia, 3, 582-584.

Meyer-Rochow, V. B. (1979). Stomach and gut contents of Carapus mourlani from starfish and a holothurian. Annales Zoologici Fennici, 16, 287-289.

Nelson, J. S., Grande, T. C., \& Wilson, M. V. (2016). Fishes of the World. Hoboken, New Jersey: John Wiley \& Sons.

Nielsen, J. G., Cohen, D. M., Markle, D. F., \& Robins, C. R. (1999). Ophidiiform Fishes of the World (Order Ophidiiformes). An annotated and illustrated catalogue of pearlfishes, cusk-eels, brotulas and other ophidiiform fishes known to date. FAO Fisheries Synopsis, 18 (125). Rome, Italy: FAO.

Paredes-Ríos, G. A., \& Balart, E. F. (1999). Corroboration of the Bivalve, Pinna rugosa, as a host of the Pacific Pearlfish, Encheliophis dubius (Ophidiiformes: Carapidae), in the Gulf of California, Mexico. Copeia, 2, 521-522.

Parmentier, E., Colleye, O., \& Lecchini, D. (2016). New insights into sound production in Carapus mourlani (Carapidae). Bulletin of Marine Science, 92, 1-8.

Parmentier, E., Fine, M., Vandewalle, P., Ducamp, J., \& Lagardère. J. (2006). Sound production in two Carapids (Carapus acus and C. mourlani) and through the sea cucumber tegument. Acta Zoologica, 87, 113-119.

Parmentier, E., Lanterbecq, D., \& Eeckhaut, I. (2016). From commensalism to parasitism in Carapidae (Ophidiiformes): heterochronic modes of development? PeerJ, 4, (e1786), 1-23. 
Parmentier, E., Mercier, A., \& Hamel, J. F. (2006). New host and geographical distribution for the pearlfish Carapus mourlani (Carapidae) with a discussion on its biology. Copeia, 1, 122-128.

Parmentier, E., \& Vandewalle, P. (2005). Further insight on Carapid-holothuroid relationships. Marine Biology, 146, 455-465.

Pawson, D. (2007). Phylum Echinodermata. In Z. Q. Zhang, \& W. A. Shear (Eds.), Linnaeus Tercentenary: Progress in Invertebrate Taxonomy. Zootaxa, 1668, 749-764.

Robertson, D. R., \& Allen, G. R. (2015). Shorefishes of the Tropical Eastern Pacific: online information system. Version 2.0. Smithsonian Tropical Research Institute, Balboa, Panamá. http://biogeodb.stri.si.edu/sftep/en/ pages.

Smith, L., Tyler, J., \& Feinberg, M. N. (1981). Population ecology and biology of the Pearlfish (Carapus bermudensis) in the Lagoon at Bimini, Bahamas. Bulletin of Marine Science, 31, 876-902.

Solís-Marín, F. A., Arriaga-Ochoa, J. A., Laguarda-Figueras, A., Frontana-Uribe, S. C., \& Durán-González, A (2009). Holothuroideos (Echinodermata: Holothuroidea) del Golfo de California, México. México: Comisión Nacional para el Conocimiento y Uso de la Biodiversidad e Instituto de Ciencias del Mar y Limnología, UNAM.

Solís-Marín, F. A., Alvarado, J. J., Abreu-Pérez, M., Aguilera, O., Alió, J., Bacallado-Aránega, J. J., ... \& Williams, S. M. (2013). Appendix. In J. J. Alvarado, \& F. A. Solís-Marín (Eds.), Echinoderm Research and Diversity in Latin America (pp. 543-654). Berlin and Heidelberg: Springer.

Solís-Marín, F. A., Laguarda-Figueras, A., Estrada-Rodríguez, P., Honey-Escandón, M., Cao-Romero, C., \& Durán-Gonzáles, A. (2014). Los asteroideos (Echinodermata: Asteroidea) del Golfo de California, México. México DF: Universidad Nacional Autónoma de México (UNAM), Instituto de Ciencias del
Mar y Limnología, Secretaría de Medio Ambiente y Recursos Naturales (Semarnat) e Instituto Nacional de Ecología y Cambio Climático (INECC).

Taylor, W. R., \& Dyke, G. C. (1985). Revised procedures for staining and clearing small fishes and other vertebrates for bone and cartilage study. Cybium, 9, 107-119.

Trott, L. B. (1970). Contributions to the biology of carapid fishes (Paracanthopterygii: Gadiformes). University of California Publications in Zoology, 89, 1-60.

Trott, L. B. (1981). A general review of the pearlfishes (Pisces, Carapidae). Bulletin of Marine Science, 31, 623-629.

Trott, L. B., \& Trott, E. E. (1972). Pearlfishes (Carapidae: Gadiformes) collected from Puerto Galera, Mindoro, Philippines. Copeia, 1972, 839-843.

Woo, S. P. (2013). The Diversity, Distribution, and Morphological Descriptions of Stichopodidae (Echinodermata: Holothuroidea) in the Vicinity of Malaysian Waters. (Master of Science dissertation). Universiti Sains Malaysia, Malaysia.

Woo, S. P. (2018). Systematic Studies on Sea Cucumbers of the Family Stichopodidae (Echinodermata: Holothuroidea). (Doctoral dissertation). Hokkaido University, Japan.

Woo, S. P., Zulfigar, Y., Tan, S. H., Kajihara, H., \& Fujita, T. (2015). Sea cucumbers of the genus Stichopus Brandt, 1835 (Holothuroidea, Stichopodidae) in Straits of Malacca with description of a new species. ZooKeys, 545, 1-26.

WoRMS Editorial Board (2021). World Register of Marine Species. http://www.marinespecies.org/

Zaman, L., Meyer, J. R., Devangam, S., Bryson, D. M., Lenski, R. E., \& Ofria, C. (2014). Coevolution drives the emergence of complex traits and promotes evolvability. PLoS Biol, 12(12), e1002023. 